\title{
Pengelolaan Gulma Kelapa Sawit (Elaeis guineensis Jacq.) Studi Kasus di Kalimantan Selatan
}

\author{
Weed Management of Oil Palm (Elaeis guineensis Jacq.) case : at South Kalimantan
}

\author{
Winda Nufvitarini, Sofyan Zaman", dan Ahmad Junaedi
}

Departemen Agronomi dan Hortikultura, Fakultas Pertanian, Institut Pertanian Bogor (Bogor Agricultural University), J1. Meranti, Kampus IPB Darmaga, Bogor 16680, Indonesia

Telp.\&Faks. 62-251-8629353 e-mail agrohort.ipb.ac.id

*Penulis untuk korespondensi: sofyan_zaman@yahoo.co.id

Disetujui 18 Januari 2016/ Published online 25 Januari 2016

\begin{abstract}
The research was conducted at Angsana Estate, South Kalimantan from February to June 2011. The data was collected from field and from reports. There were two methods on weed control according to weed problem at site, first inter-row and second circle weeding. The vegetation analysis showed that broadleaves were dominant at field. Coefficient weed comunity was than $75 \%$, indicating non homogen. Weeds were controled in Angsana Estate consisted of manually and chemically. Manual control performed on young (immature) and productive diving rainy weather. Chemical control was performed using systemic herbicides according to principles of sustainable palm oil management through Block Spraying System (BSS). Some weed species were maintained for a specific purpose (beneficial plant) $s u c h$ as maintain soil moisture, increase organic matter and nutrients in the soil and manage pests, They were Euphorbia heterophylla, Cassia cobanensis, Antigonon leptopus and Turnera subulata.
\end{abstract}

Keyword: beneficial plant, weed in palm oil

\begin{abstract}
ABSTRAK
Kegiatan bertujuan untuk mengetahui manajemen pengendalian gulma kelapa sawit. Kegiatan dilaksanakan dari bulan Februari sampai Juni 2011. Pengumpulan data dilakukan di Angsana Estate, Kalimantan Selatan. Metode tidak langsung dengan melakukan studi pustaka berupa literatur dan laporan kebun. Gulma berdaun lebar banyak mendominasi areal perkebunan. Perbandingan nilai koefisien komunitas gulma tiap tahun tanam tidak homogen, nilai C $<75 \%$. Pengendalian gulma dilakukan di dua tempat yaitu di gawangan dan piringan, secara manual dan kimiawi. Pengendalian secara manual dilakukan pada tanaman yang masih muda (TBM) dan TM. Pengendalian secara kimiawi dengan menggunakan herbisida sistemik sesuai dengan pedoman prinsip dan kriteria kebun yang berkelanjutan dengan Block Spraying System (BSS). Tidak semua gulma di ASE dikendalikan, beberapa jenis gulma dipelihara untuk tujuan tertentu (beneficial plant) seperti menjaga kelembaban tanah, meningkatkan bahan organik dan nutrisi dalam tanah serta dapat mengatasi serangan hama. Beneficial plant tersebut antara lain Euphorbia heterophylla, Cassia cobanensis, Antigonon leptopus dan Turnera subulata.
\end{abstract}

Kata kunci: gulma kelapa sawit, tanaman berguna (beneficial plant) 


\section{PENDAHULUAN}

Sektor agribisnis kelapa sawit memberikan dampak positif dalam pembangunan nasional. Sunarko (2009) menyebutkan manfaat pengembangan agribisnis kelapa sawit antara lain peningkatan pendapatan petani, menyediakan bahan baku untuk industri hilir lainnya, peningkatan kesempatan kerja dan mendukung upaya pengembangan wilayah. Dalam proses pengembangannya, luasan areal perkebunan kelapa sawit di Indonesia juga mengalami peningkatan pada tahun 2009 luasan areal seluas 7.8 juta ha menjadi 8.3 juta ha pada tahun 2010 . Peningkatan luas areal perkebunan kelapa sawit pada tahun 2011 seluas 8.9 juta ha meningkat pada tahun 2012 seluas 9.1 juta ha. Peningkatan luas areal perkebunan kelapa sawit juga diimbangi dengan peningkatan produktivitas kelapa sawit. Produktivitas kelapa sawit tahun 2009 sebesar $3487 \mathrm{~kg} \mathrm{ha}^{-1}$, data ini mengalami peningkatan pada tahun 2010 sebesar $3 \quad 595 \quad \mathrm{~kg} \mathrm{ha}^{-1}$. Tahun 2011, produktivitas kelapa sawit $3526 \mathrm{~kg} \mathrm{ha}^{-1}$ mengalami peningkatan tahun 2012 menjadi 3 $571 \mathrm{~kg} \mathrm{ha}^{-1}$ (Ditjenbun, 2013). Peningkatan produktivitas kelapa sawit ini harus dipertahankan dengan cara melakukan pemeliharaan terhadap kebun kelapa sawit, salah satunya yaitu dengan adanya pengelolaan gulma yang tepat.

Gulma merupakan tumbuhan yang tumbuh ditempat yang tidak dikehendaki oleh manusia atau tumbuhan yang kegunaannya belum diketahui (Tjitrosoedirdjo et al., 1984). Hadirnya gulma diperkebunan dapat menurunkan produksi karena gulma melakukan kompetisi dengan tanaman budi daya dalam memperebutkan air tanah, cahaya matahari, unsur hara, udara dan ruang tumbuh. Hal ini mengakibatkan tanaman budi daya terganggu pertumbuhannya, sehingga dapat menurunkan hasil produksi. Selain itu, gulma juga dapat menurunkan mutu hasil tanaman akibat dari kontaminasi dengan bagian-bagian gulma. Gulma juga dapat menjadi inang bagi hama dan patogen yang menyerang tanaman, mengganggu tata guna air, mengeluarkan senyawa alelopati yang dapat mengganggu pertumbuhan tanaman dan meningkatkan biaya usaha tani. Keberadaan gulma banyak menimbulkan dampak negatif pada usaha perkebunan, untuk itu perlu adanya pengelolaan gulma yang teratur dan terencana.

Menurut Sukman dan Yakup (2002), pengelolaan gulma merupakan suatu tindakan pencegahan terhadap gulma, pengendalian gulma dengan cara yang sudah ditetapkan. Pahan (2008) menambahkan pengelolaan gulma yang dilakukan harus tepat agar tidak meningkatkan daya saing gulma. Pengelolaan gulma pada prinsipnya merupakan usaha untuk meningkatkan daya saing tanaman budi daya dan melemahkan daya saing gulma. Keunggulan tanaman budidaya harus ditingkatkan sedemikian rupa sehingga gulma tidak mampu mengembangkan pertumbuhannya secara berdampingan atau pada waktu bersamaan dengan tanaman budidaya.

Tujuan kegiatan adalah mempelajari teknis dan meningkatkan pengetahuan tentang budidaya tanaman kelapa sawit, dan mempelajari serta mengetahui manajemen pengelolaan gulma.

\section{BAHAN DAN METODE}

Kegiatan dilaksanakan pada bulan Februari sampai Juni 2011 di Perkebunan Kelapa Sawit Angsana Estate, Kalimantan Selatan. Metode yang digunakan adalah metode langsung dan metode tidak langsung. Metode langsung dengan melaksanakan dan mempelajari seluruh kegiatan di lapangan sebagai karyawan harian lepas (KHL) selama satu bulan, pendamping mandor selama satu bulan dan pendamping asisten divisi selama dua bulan terakhir. Metode tidak langsung yaitu studi pustaka berupa literatur dan laporan kebun.

Data primer diperoleh dari analisis vegetasi gulma dibeberapa blok tertentu berdasarkan tahun tanam baik itu tanaman yang sudah menghasilkan maupun tanaman belum menghasilkan. Analisis vegetasi dilakukan dengan menggunakan kuadran berukuran $50 \mathrm{~cm} \times 50 \mathrm{~cm}$. Jumlah sampel yang diambil 5\% dari luasan lahan tiap tahun tanam. Dilakukan pemanenan gulma pada kuadran untuk pengamatan Nisbah Jumlah Dominasi (NJD) dan koefisien komunitas (C). NJD diperoleh dengan menentukan frekuensi, kerapatan dan bobot kering gulma. Kerapatan diperoleh dengan menghitung jumlah individu tiap spesies gulma tertentu dalam petak contoh. Frekuensi ditentukan dengan cara menghitung jumlah petak contoh yang memuat spesies tersebut. Bobot kering ditentukan dengan cara mengeringkan spesies tersebut selama beberapa hari, kemudian ditimbang bobot keringnya. Koefisien komunitas digunakan untuk membandingkan dua komunitas vegetasi atau dua macam vegetasi dari dua daerah (Tjitrosoedirdjo et al., 1984). Data sekunder yang diperoleh 
seperti peta wilayah administrasi kebun, letak geografis, peta kebun, data iklim, data produksi, data perawatan kebun seperti data program pemupukan dan pengendalian gulma serta data pendukung lainnya.

Data pengamatan petak contoh yang diperoleh dikelompokkan dan diolah dengan menggunakan analisis vegetasi gulma metode kuadrat untuk mencari Nisbah Jumlah Dominasi (NJD) gulma dan koefisien komunitas (C). Data sekunder dan informasi yang didapat melalui pengumpulan laporan bulanan, laporan tahunan, arsip kebun yang lain diolah secara deskriptif.

\section{HASIL DAN PEMBAHASAN}

\section{Kondisi dan Jenis Gulma}

Gulma yang tumbuh disuatu daerah akan berbeda di daerah lainnya meskipun pada tanaman budi daya yang sama. Kondisi gulma pada suatu lahan dapat diketahui dengan cara analisis vegetasi. Menurut Tjitrosoedirdjo et al. (1984) analisis vegetasi ditunjukkan untuk mempelajari tingkat suksesi, evaluasi hasil pengendalian gulma, perubahan flora sebagai akibat pengendalian tertentu dan evaluasi herbisida untuk menentukan aktivitas suatu herbisida terhadap jenis gulma di lapangan. Parameter kuantitatif yang digunakan untuk analisis vegetasi antara lain persentase penyebaran gulma, kerapatan, frekuensi dan dominasi gulma. Nilai Nisbah Jumlah Dominasi (NJD) disajikan dalam Tabel 1.

Hasil analisis vegetasi yang dilakukan (Tabel 1) menunjukkan bahwa jenis-jenis gulma yang ada di ASE cukup bervariasi. Jenis gulma yang tumbuh di areal TM ditemukan juga di areal TBM. Nilai NJD menurut golongan gulma menunjukkan golongan gulma daun lebar banyak mendominasi di areal perkebunan. Gulma daun lebar tersebut antara lain Ageratum conyzoides, Borreria alata, Kentosan, Melastoma malabatricum, dan Micrania micranta. Gulma golongan rumput banyak mendominasi areal TM, gulma tersebut antara lain Axonopus compressus, Centotheca lappaceae, dan Cynodon dactilon. Gulma golongan teki-tekian yang mendominasi yaitu Cyperus iria dan Scleria sumatrensis.

Tabel 1. Nilai NJD gulma di ASE

\begin{tabular}{|c|c|c|c|c|c|c|c|}
\hline \multirow{2}{*}{ Nama spesies } & \multicolumn{7}{|c|}{ Tahun tanaman } \\
\hline & 1996 & 1998 & 1999 & 2000 & 2006 & 2007 & 2008 \\
\hline & \multicolumn{7}{|c|}{ 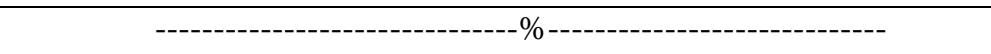 } \\
\hline \multicolumn{8}{|l|}{ Daun lebar } \\
\hline Ageratum conyzoides & 13.01 & 8.62 & 18.89 & 20.17 & 21.90 & 10.97 & 20.52 \\
\hline Borreria alata & 13.95 & 17.69 & 6.56 & 14.21 & 14.39 & 14.09 & 18.17 \\
\hline Cleome rutiduspermae & 0.00 & 0.00 & 0.00 & 9.69 & 11.37 & 0.00 & 4.15 \\
\hline Kentosan & 9.65 & 7.42 & 3.81 & 6.56 & 4.76 & 2.68 & 0.00 \\
\hline Melastoma malabatricum & 6.34 & 4.04 & 2.07 & 8.89 & 11.71 & 14.38 & 14.90 \\
\hline Micrania micranta & 0.00 & 0.00 & 2.05 & 1.53 & 0.42 & 5.23 & 0.95 \\
\hline gulma lain & 5.26 & 5.21 & 10.95 & 26.02 & 21.40 & 27.42 & 17.40 \\
\hline Sub total & 48.20 & 42.96 & 44.33 & 87.08 & 85.96 & 74.78 & 76.09 \\
\hline \multicolumn{8}{|l|}{ Rumput } \\
\hline Axonopus compressus & 17.77 & 13.99 & 19.24 & 0.00 & 1.97 & 0.00 & 0.00 \\
\hline Centotheca lappaceae & 13.70 & 15.46 & 5.17 & 0.38 & 0.00 & 0.00 & 0.00 \\
\hline Cynodon dactilon & 8.87 & 6.23 & 9.32 & 0.53 & 0.00 & 0.00 & 0.00 \\
\hline Gulma lain & 10.13 & 14.29 & 51.31 & 3.93 & 4.86 & 10.47 & 6.40 \\
\hline Sub total & 50.47 & 49.97 & 51.31 & 3.93 & 4.86 & 10.47 & 6.40 \\
\hline \multicolumn{8}{|l|}{ Teki } \\
\hline Cyperus iria & 0.02 & 0.18 & 1.34 & 2.49 & 0.75 & 1.81 & 3.51 \\
\hline Scleria sumatrensis & 1.29 & 6.87 & 4.36 & 8.99 & 9.18 & 14.76 & 17.51 \\
\hline Sub total & 99.98 & & & & & & \\
\hline Total & 100.00 & 100.00 & 100.00 & 100.00 & 100.00 & 100.00 & 100.00 \\
\hline
\end{tabular}

Perbedaan tahun tanam kelapa sawit mengakibatkan penutupan kanopi yang berbeda, sehingga jenis gulma yang tumbuh dominan memiliki perbedaan disetiap tahun tanamnya. Tanaman kepala sawit menghasilkan (TM) memiliki tajuk yang saling menutup sehingga cahaya masuk ke permukaan tanah tidak banyak. Kondisi yang demikian akan menghambat pertumbuhan gulma di bawah tajuk karena cahaya matahari kurang bagi pertumbuhan gulma. Kondisi ini berbeda dengan tanaman kelapa sawit yang masih muda 
(TBM). Syahputra et al. (2011) mengungkapkan bahwa kondisi lahan pada TBM masih terbuka sehingga penetrasi cahaya matahari lebih banyak, keadaan ini dapat menyebabkan biji gulma yang pada awalnya dorman di permukaan tanah menjadi terpicu untuk berkecambah.

Koefisien komunitas digunakan untuk menilai adanya variasi atau kesamaan dari berbagai komunitas dalam suatu area. Suatu area dikatakan memiliki kesamaan apabila nilai dari koefisien komunitas (C) di atas 75\% (Tjitrosoedirdjo et al., 1984). Hasil perhitungan koefisien komunitas dengan membandingkan tiap tahun tanaman kelapa sawit diperoleh nilai C $<75 \%$ (Tabel 2). Hal ini dapat disimpulkan bahwa perbandingan komunitas gulma tiap tahun tanam adalah tidak homogen. Syahputra et al. (2011) menyatakan perbedaan komunitas dapat menyebabkan perbedaan pengelolaan gulma pada kebun.

Tabel 2. Nilai koefisien komunitas (C) gulma di ASE

\begin{tabular}{|c|c|c|c|c|c|c|}
\hline \multirow{2}{*}{ Tahun tanam } & \multicolumn{6}{|c|}{ Tahun tanam } \\
\hline & 1998 & 1999 & 2000 & 2006 & 2007 & 2008 \\
\hline & \multicolumn{6}{|c|}{$\mathrm{C}(\%)$} \\
\hline 1996 & 40.15 & 34.72 & 22.19 & 21.76 & 18.85 & 18.52 \\
\hline 1998 & & 32.96 & 17.21 & 17.65 & 17.24 & 18.64 \\
\hline 1999 & & & 26.51 & 22.92 & 20.61 & 21.29 \\
\hline 2000 & & & & 43.76 & 34.38 & 36.09 \\
\hline 2006 & & & & & 33.67 & 37.05 \\
\hline 2007 & & & & & & 36.95 \\
\hline
\end{tabular}

\section{Organisasi Pengendalian Gulma}

Pelaksanaan pengendalian gulma di kebun perlu adanya koordinasi yang baik agar tujuan pengendalian gulma itu sendiri dapat berjalan sesuai dengan rencana. Manajer kebun bertugas mengorganisasikan dan mengambil keputusan di kebun. Manajer kebun akan memberikan tugas kepada senior asisten untuk melakukan tugas perawatan kebun salah satunya yaitu pengendalian terhadap gulma. Senior asisten akan memberikan tugas terkait dengan pelaksanaan pengendalian gulma baik secara manual ataupun dengan menggunakan bahan kimia kepada asisten divisi. Pengendalian gulma secara manual dilaksanakan langsung oleh masing-masing divisi dan dikoordinir oleh mandor perawatan.

Pengendalian gulma secara kimia dibuat dalam satu tim khusus yang berada di divisi III, namun bertugas untuk semua divisi kebun yang dilakukan secara bergiliran. Terkonsetrasinya pengendalian gulma secara kimia dinilai memiliki beberapa keunggulan antara lain lebih terorganisasi, pencampuran bahan dan konsentrasi lebih terkontrol, pemakaian bahan lebih terdeteksi dan efisien, perawatan/ perbaikan alat lebih efektif karena kerusakan alat mudah terdeteksi, efisiensi terhadap tenaga kerja dan supervisi.

Senior asisten memberikan tugas kepada asisten divisi III untuk melaksanakan pengendalian gulma secara kimia. Asisten divisi III akan berkoordinasi dengan gudang sentral dan traksi untuk mempersiapkan bahan kimia berupa herbisida dan transportasi. Ketika akan aplikasi herbisida ke divisi lain, asisten divisi III akan berkoordinasi langsung dengan asisten divisi yang bersangkutan. Hal ini dilakukan agar pengerjaan aplikasi herbisida tidak bersamaan dengan kegiatan kebun yang lain seperti kegiatan panen dan pemupukan.

Asisten divisi III akan memberikan tugas langsung kepada mandor semprot dalam melaksanakan pengendalian gulma secara kimia. Asisten divisi III akan membuat dan memberikan bon permintaan barang berupa herbisida kepada mandor semprot. Bon permintaan barang harus mengetahui senior asisten dan manajer kebun, baru selanjutnya barang bisa diambil di gudang sentral. Dari gudang sentral, pencampuran herbisida dilakukan di rumah BSS oleh mandor semprot yang saksikan oleh asisten Divisi III.

Pengendalian gulma secara kimia di ASE terkonsentrasi pada blok per blok yang dinamakan dengan Block Spraying System (BSS). Tim BSS sendiri dibagi menjadi dua yaitu tim TSK (Tim Semprot Keliling) dan tim MHS (Micro Herby Sprayer). Pengerjaan tim TSK terkonsentrasi di gawangan baik pada tanaman kelapa sawit TBM ataupun TM, sedangkan tim MHS lebih terkonsentrasi ke piringan kelapa sawit TM.

Organisasi ditingkat penyemprotan terdiri dari mandor TSK/MHS, supir TSK, tukang air dan tenaga penyemprot. Jumlah tenaga kerja tim TSK sebanyak 20 orang dan jumlah tenaga kerja tim MHS sebanyak 7 orang. Pengendalian gulma secara kimia merupakan pekerjaan yang membutuhkan ketelitian dan ketepatan, sehingga 
tenaga kerja tim semprot ini tidak boleh digantiganti dan sebagian besar adalah wanita. Pekerjaan pengendalian gulma secara kimia merupakan pekerjaan halus yang membutuhkan keterampilan khusus, tenaga kerja wanita mampu memperhitungkan kecepatan jalan, kekuatan memompa dan menyemprotkan herbisida secara merata sehingga pemakaian herbisida tidak berlebihan.

Mandor memberi arahan kepada supir dan tukang air berapa dosis per kap herbisida yang digunakan di lapangan. Lalu membagi hancak penyemprot dan melakukan pengawasan penuh terhadap pekerjaan di lapangan seperti kualitas semprotan, jam kerja karyawan, dan pendataan hasil yang berorientasi pada kualitas semprot. Penyemprotan harus mengenai gulma sasaran yang dikendalikan. Pengisian larutan dilakukan oleh tukang air yang diawasi oleh supir TSK, sedangkan mandor tetap di lapangan mengawasi pelaksanaan penyemprotan. Program semprot setiap bulannya dibuat 20 hari kerja, sehingga pada hari kerja terdapat hari hujan maka pengganti harinya diambil dari lima hari yang telah dicadangkan (dalam satu bulan dihitung 25 hari kerja). Pada saat hari hujan, pekerjaan penyemprotan dialihkan ke pekerjaan pengendalian gulma secara manual sehingga alat kerja cadangan (cados) harus dibawa ke lapangan setiap hari kerja.

\section{Teknik Pengendalian Gulma}

Pengendalian gulma pada prinsipnya yaitu mengendalikan pertumbuhan gulma yang tumbuh di areal tanaman kelapa sawit untuk menekan adanya kompetisi. Adanya pengendalian gulma diharapkan dapat melemahkan daya saing gulma terhadap tanaman kelapa sawit yang dibudidayakan. Pengendalian gulma mengacu pada pengendalian gulma secara terpadu sesuai dengan prinsip dan kriteria untuk menjadi kebun kelapa sawit yang berkelanjutan. Metode pengendalian gulma yang digunakan atas dasar pertimbangan secara ekologi, sehingga pengendalian gulma diutamakan kepada populasi gulma yang merugikan saja.

Pengendalian gulma dilakukan di dua tempat yaitu di piringan dan di gawangan. Fokus kegiatan pengendalian gulma ini antara lain yaitu gulma umum yang berada di piringan dan pengendalian gulma di gawangan. Rotasi pengendalian gulma sebanyak empat kali dalam setahun, dimana pengendalian secara kimia dilakukan sebanyak tiga kali dan pengendalian manual dilaksanakan sebanyak satu kali dalam setahun.
Pengendalian gulma secara manual banyak dilakukan pada tanaman kelapa sawit yang masih muda (TBM). Pengendalian gulma secara manual pada areal TM dilakukan oleh tim TSK dan MHS ketika tidak ada aplikasi herbisida. Sasaran pengendalian gulma secara manual adalah piringan dan gawangan kelapa sawit. Metode pengendalian gulma secara manual pada piringan disebut piringan manual atau raking. Pengendalian gulma secara manual di gawangan disebut dengan berantas tanaman pengganggu (BTP), cara kerjanya dengan cara dongkel anak kayu (DAK) dan tebas rendahan. Tujuan pengendalian gulma secara manual adalah untuk mengurangi kehilangan unsur hara dan memperlancar kegiatan kebun lainnya seperti kegiatan panen dan pemupukan.

Keunggulan dari pengendalian gulma secara manual antara lain hasil yang didapat cepat terlihat, mudah untuk dilaksanakan dan secara ekologi dapat menghindarkan dampak polusi lingkungan. Dampak negatif dari pengendalian gulma secara manual antara lain memerlukan banyak tenaga kerja dan membutuhkan waktu yang cukup lama sehingga terjadi peningkatan terhadap biaya perawatan kebun.

Pengendalian gulma secara manual juga menyebabkan terjadinya pelukaan akar tanaman kelapa sawit akibat peralatan mekanis dan dapat menyebabkan terjadinya erosi permukaan. Peralatan yang digunakan untuk pengendalian gulma secara manual antara lain cangkul dodos (cados), garukan, dan parang.

Pengendalian gulma secara manual di gawangan lebih banyak dilakukan untuk mengendalikan gulma jenis anak kayu. Gulma anak kayu dikendalikan dengan cara mendongkel/ membongkar gulma tersebut hingga keakarnya kemudian gulma yang sudah dibongkar diletakkan di gawangan mati. Metode pengendalian gulma anak kayu, pelaksanaan di lahan sering tidak efektif, yaitu dengan cara ditebas. Kesalahan metode pengendalian gulma anak kayu memungkinkan gulma tersebut tumbuh dengan cepat, sehingga sebelum rotasi pengendalian gulma berikutnya gulma ini telah tumbuh dengan lebat. Jenis gulma yang dikendalikan secara manual antara lain anakan sawit (kentosan), Clibadium suriname, Melastoma malabatricum, Chromolaena odorata, Lantana camara dan gulma epifit.

Kegiatan raking atau garuk piringan yaitu membersihkan piringan kelapa sawit dari brondolan hitam yang tidak terambil, anakan sawit, bunga jantan yang luruh dan gulma-gulma lainnya, sehingga piringan bersih dalam kondisi 
bersih bebas dari gulma. Kegiatan garuk piringan pada TBM selain membersihkan piringan dari gulma dan kotoran, gulma yang merambat seperti Micrania micranta juga diberantas. Jenis gulma Micrania micranta yang merambat dan menutup tajuk kelapa sawit mengakibatkan tanaman kelapa sawit kekurangan sinar matahari, sehingga menyebabkan tanaman menjadi kerdil, tidak berbuah, hingga mati.

Adriadi et al. (2012) menyebutkan Micrania micranta merupakan tumbuhan yang mudah menyebar dan berkembang biak dengan cepat. Tumbuhan ini juga memiliki daya yang cepat untuk tumbuh di lingkungan apa saja seperti lahan lembab dan lahan kering, sehingga tumbuhan ini merupakan ancaman yang besar bagi tanaman pertanian karena mengancam dalam pengambilan unsur hara.

Kegiatan raking/ garuk piringan juga dilakukan pada kelapa sawit TM, jenis kegiatannya yaitu dengan mencabuti gulma epifit yang tumbuh pada pokok kelapa sawit (sanitasi pokok). Sanitasi pokok dilakukan dengan tujuan untuk memudahkan kegiatan panen dan pengutipan brondolan sehingga meminimalkan resiko kehilangan dan terjadinya serangan hama. Gulma epifit merupakan gulma yang tumbuh menempel pada batang kelapa sawit, umumnya berupa pakis-pakisan, beringin dan kayuan lainnya (Ginting et al., 2004). Pengendalian gulma epifit ini dengan cara ditabas dan dicabut dari pokok kelapa sawit, kemudian di buang ke gawangan mati. Pakis-pakisan seperti Neprolephis biserrata tetap dipertahankan untuk menjaga kelembaban pokok kelapa sawit, akan tetapi jika gulma ini tumbuh sampai mengganggu tanaman pokok ataupun menghambat kegiatan panen dan pemeliharaan lainnya diperlukan pengendalian khusus. Pengendalian khusus tersebut seperti mencabut gulma tersebut, namun masih disisakan untuk memjaga kelembaban pokok kelapa sawit. Menurut Syahputra et al. (2011), golongan gulma pakis-pakisan memperbanyak diri melalui spora dan akar rimpang, keadaan ini menyebabkan mudahnya gulma tersebut tumbuh dan menyebar.

Pengendalian gulma secara kimia dengan menggunakan herbisida. Herbisida merupakan bahan senyawa beracun yang dimanfaatkan untuk membunuh atau mengendalikan gulma. Penggunaan herbisda sesuai dengan SOP yang mengacu pada kriteria dan prinsip kebun yang berkelanjutan.

Pengendalian gulma secara kimia dilakukan pada piringan, pasar rintis, TPH dan gawangan. Pengendalian gulma secara kimia dengan melihat peta pemeliharaan yang terdapat di setiap kantor divisi. Peta pemeliharaan terdiri atas peta identifikasi gawangan dan piringan dalam satu tahun, peta program pemupukan dan tabel aplikasi, peta program gawangan dan piringan manual beserta tabel aplikasi, peta program gawangan dan piringan kimia beserta tabel aplikasi, peta luasan kebun, peta sumur pantau, peta seksi panen, dan peta seksi tunas progresif. Pada peta identifikasi gawangan dan piringan di ASE, terdapat informasi mengenai kondisi umum pertumbuhan gulma. Keadaan gulma di lapangan disimbolkan dengan warna. Area yang diberi warna hijau menunjukkan kondisi gulma di area tersebut ringan. Warna kuning menunjukkan kondisi gulma di area tersebut sedang. Warna merah menunjukkan kondisi gulma di area tersebut berat.

Pada peta pemeliharaan, juga terdapat peta program gawangan dan pringan kimia dan manual serta terdapat tabel aplikasi masingmasing program. Peta ini menginformasikan mengenai rotasi pengendalian gulma baik di gawangan maupun di piringan selama setahun. Tabel aplikasi digunakan untuk memantau blok mana saja yang sudah diaplikasi sesuai dengan peta identifikasi gawangan dan piringan serta peta program pemeliharan. Adanya tabel aplikasi asisten divisi dapat memantau secara tertulis terjadinya permasalah pengendalian gulma di lapangan.

$$
\text { Pengendalian gulma dengan }
$$

menggunakan herbisida memiliki beberapa keunggulan antara lain mengurangi tenaga kerja; dapat mengendalikan gulma yang tumbuh bersamaan dengan tanaman budi daya yang sulit disiangi; mampu mengendalikan gulma sejak awal; mengurangi kerusakan dan pelukaan akar dampak penyiangan secara mekanis; erosi permukaan dapat dikurangi; dan banyak gulma yang bersifat pohon lebih mudah ditangani dengan menggunakan herbisda. Pengendalian gulma dengan menggunakan herbisida selain menguntungkan juga memiliki kelemahan antara lain memerlukan tenaga ahli untuk pemakaiannya baik yang berhubungan dengan keselamatan dan dosis. Pemakaian herbisida yang berlebihan dapat berdapak secara ekologi yaitu menimbulkan polusi lingkungan serta toksisitas bagi tanaman budidaya itu sendiri (Tjitrosoedirdjo et al., 1984).

Jenis herbisida yang digunakan bersifat sistemik. Menurut Sukman dan Yakup (2002), herbisida sistemik berarti herbisida yang diberikan pada gulma setelah diserap oleh jaringan daun kemudian ditranlokasikan keseluruh bagian gulma tersebut sehingga akan mengalami kematian total. Aplikasinya dengan 
cara melakukan penyemprotan ke daun atau menyiramkan ke akar tanaman. Jenis herbisida yang digunakan disajikan pada Tabel 3.

Tabel 3. Jenis Herbisida yang digunakan di PT ASE, Kalimantan Selatan

\begin{tabular}{cllcc}
\hline No & \multicolumn{1}{c}{ Merek dagang } & \multicolumn{1}{c}{ Bahan aktif } & Kandungan bahan aktif & Sifat \\
\hline 1 & Ally 20 WDG & Metil metsulfuron & $20 \%$ & sistemik \\
2 & Starane & Fluroksipir & $200 \mathrm{~g} \mathrm{~L}^{-1}$ & sistemik \\
3 & Kenlon & Triklopir butoksi, Etil ester & $480 \mathrm{~g} \mathrm{~L}^{-1}$ & sistemik \\
4 & Metafuron 20 WP & Metil metsulfuron & $20 \%$ & sistemik \\
5 & Basta & Amonium glufosinat & $150 \mathrm{~g} \mathrm{~L}^{-1}$ & sistemik \\
6 & Prima Up & Isopropilamina glifosat & $480 \mathrm{~g} \mathrm{~L}^{-1}$ & sistemik \\
\hline
\end{tabular}

Sumber: Kantor Besar ASE 2011

Pemakaian herbisida dengan cara mencampurkan herbisida-herbisida tertentu dengan dosis dan konsentrasi yang sudah ditetapkan oleh bagian riset (Tabel 4). Dosis merupakan jumlah herbisida yang dibutuhkan untuk menyemprot gulma persatuan luas (ha). Konsentrasi merupakan perbandingan antara jumlah herbisida dengan pelarutnya (air). Pemakaian herbisida dengan cara dicampur berfungsi untuk mendapatkan efek sinergis dan meningkatkan toksisitas terhadap jasad sasaran ataupun memperoleh sifat kimia fisik yang optimal dan penetrasi herbisida, memperluas spektrum pengendalian gulma serta dapat menghemat biaya. Menurut Manual Referensi Agronomi Minamas Plantation (2008) dosis herbisida yang digunakan untuk pengendalian gulma sangat tergantung dari jenis gulma sasaran. Barus (2007) menambahkan dosis herbisida yang digunakan sangat tergantung pada jenis dan kondisi gulma sasaran, kondisi cuaca, kondisi areal perkebunan, serta jenis sprayer dan nozzle yang digunakan. Setiap jenis produk herbisida memiliki dosis rekomendasi yang dianjurkan oleh formulatornya. Sasaran pengendalian gulma antara di piringan dan di gawangan kelapa sawit berbeda maka campuran dan dosis herbisida yang digunakan juga berbeda.

Tabel 4. Dosis herbisida campuran yang digunakan di ASE

\begin{tabular}{|c|c|c|}
\hline Campuran herbisida & Dosis & Sasaran \\
\hline $\begin{array}{l}\text { Metil metsulfuron + Isapropilamina } \\
\text { glifosat }\end{array}$ & $18 \mathrm{gr} \mathrm{ha}^{1}+175 \mathrm{ml} \mathrm{ha}^{1}$ & Mengendalikan gulma di piringan \\
\hline Fluroksipir + Isapropilamina glifosat & $20 \mathrm{ml} \mathrm{ha}^{-1}+200 \mathrm{ml} \mathrm{ha}^{-1}$ & Mengendalikan gulma di piringan \\
\hline $\begin{array}{l}\text { Triklopir butoksida, Etil ester }+ \\
\text { Isapropilamina glifosat }\end{array}$ & $160 \mathrm{ml} \mathrm{ha}^{-1}+180 \mathrm{ml} \mathrm{ha}^{-1}$ & $\begin{array}{l}\text { Mengendalikan gulma kentosan dan di } \\
\text { gawangan }\end{array}$ \\
\hline Amonium glufosinat + Metil metsulfuron & $200 \mathrm{ml}^{-1} \mathrm{ha}+6 \mathrm{gr} \mathrm{ha}^{-1}$ & $\begin{array}{l}\text { Mengendalikan gulma di gawangan dan anakan } \\
\text { kayu }\end{array}$ \\
\hline
\end{tabular}

Pengendalian gulma secara kimia dilakukan di piringan dan pasar pikul saja (jalan angkong) dengan cara disemprot. Penyemprotan dilakukan secara sporadis, hanya pada gulma sasaran. Area penyemprotan yang dilakukan selain area buffer zone. Menurut Manual Referensi Agronomi Minamas (2008) area buffer zone merupakan kawasan yang ada di sekitar sungai, berjarak $100 \mathrm{~m}$ dari sungai yang harus dijaga kelestariannya sehingga mampu mendukung sebagian kawasan penyangga. Di area buffer zone ini tidak boleh dilakukan pekerjaan dengan perlakuan kimia hanya boleh dilakukan dengan manual. Area ini juga ditanami dengan beberapa tanaman penyangga seperti mahoni dan bambu. Batas daerah buffer zone kurang $50 \mathrm{~m}$ dari tepi sungai dan diberi tanda cat kuning.

\section{Tanaman Berguna (Beneficial Plant)}

Gulma disamping merugikan juga memberikan manfaat bagi kebun. Gulma juga dapat dijadikan sebagai tanaman berguna (beneficial plants). Menurut Manual Referensi Agronomi Minamas (2008) tanaman berguna (benerficial plants) adalah tanaman yang mempunyai unsur perangsang alamiah untuk menarik populasi musuh-musuh alami hama ulat api dan ulat kantong pada tanaman kelapa sawit. Menurut Tjitrosoedirdjo et al. (1984) menyatakan jika tingkat preferensi hama lebih besar pada gulma maka hadirnya gulma dapat mengurangi intensitas kerusakan oleh hama pada tanaman budi daya, walaupun demikian harus dipertimbangkan pula peranan gulma sebagai pesaing bagi tanaman budi daya.

Penanaman beneficial plants secara benar dan berkelanjutan dapat mengatasi serangan hama yang serius. Penangan serangan hama dengan 
menggunakan beneficial plants ini diharapkan dapat mengurangi penggunaan bahan kimia pada tahun-tahun berikutnya. Empat spesies tanaman yang dibudidayakan antara lain Euphorbia heterophylla, Cassia cobanensis, Antigonon leptopus, dan Turnera subulata. Menurut PPKS (2005) Euphorbia heterophylla berperan dalam pengendalian hayati ulat api dan ulat kantong yaitu sebagi sumber makanan yang berupa nektar dari kelenjar ekstra floral bagi imago (serangga dewasa), parasitoid ulat kantong (Metisa plana) dan ulat api. Kelenjar ekstra floral dari Euphorbia heterophylla ini terdapat di dekat pangkal bunga atau buah, parasitoid akan menghisap nektar dari kelenjar ekstra floral tumbuhan tersebut. Jenis parasitoid antara lain Systropus roepkei Meig, Dolichogenidea nixon spp., Brachymeria lasus Walker, dan Goryphus bunoh.

Beneficial plants diperbanyak dengan cara stek dan perbanyakan biji. Perbanyakan tanaman ini lebih banyak menggunakan stek, karena rendahnya tingkat keberhasilan pada perbanyakan melalui biji dan biji sulit didapat. Cara penanaman beneficial plants ini yaitu $60 \%$ Cassia cobanensis, 20\% Antigonon leptopus dan 20\% Tunerra subulata. Dalam setiap 10 mbeneficial plants ditanam $6 \mathrm{~m}$ Cassia cobanensis dan diapit oleh jarak masing-masing 2 $\mathrm{m}$ untuk ditanami Antigonon leptopus dan Tunerra subulata. Penanamannya dilakukan di sebelah kanan-kiri jalan yang terbuka dan di pinggir blok kebun. Penanaman beneficial plants, lebih diutamakan pada areal-areal yang memiliki sejarah serangan hama ulat daun.

\section{KESIMPULAN}

Hasil analisis vegetasi jenis gulma berdaun lebar banyak mendominasi areal perkebunan. Perbandingan nilai koefisien komunitas gulma tiap tahun tanam yang ada adalah tidak homogen, nilai $\mathrm{C}<75 \%$. Pengendalian gulma dilakukan di dua tempat yaitu di gawangan dan piringan. Pengendalian gulma dilakukan secara manual dan kimiawi. Pengendalian secara manual dilakukan pada tanaman yang masih muda (TBM) dan TM apabila cuaca hujan. Pengendalian secara kimiawi dengan menggunakan herbisda sistemik. Penggunaan herbisida dilakukan sesuai dengan pedoman prinsip dan kriteria kebun yang berkelanjutan. Pengendalian gulma secara kimia, dilakukan secara terorganisasi dan dinamakan dengan Block Spraying System (BSS). Tidak semua gulma dikendalikan, beberapa jenis gulma dikembangbiakan untuk tujuan tertentu (beneficial plant) seperti menjaga kelembaban tanah, meningkatkan bahan organik dan nutrisi dalam tanah serta dapat mengatasi serangan hama. Beneficial plant tersebut antara lain Euphorbia heterophylla, Cassia cobanensis, Antigonon leptopus dan Turnera subulata.

\section{DAFTAR PUSTAKA}

Adriadi, A., Chairul, Solfiyeni. 2012. Analisis vegetasi gulma pada perkebunan kelapa sawit (Elais guineensis Jacq) di Kilangan, Muara Bulian, Batang Hari. J. Bio. UA. 1(2):108-115.

Barus, E. 2003. Pengendalian Gulma di Perkebunan. Yogyakarta (ID): Kanisius.

[Ditjenbun] Direktorat Jenderal Perkebunan. 2013. Statistik Perkebunan Tahun 20082012 [Internet]. [diunduh 2013 Mei 3]. Tersedia pada: http://www.ditjenbun. deptan.go.id.

Ginting, K., Sutarta, E, S., Purba, R, Y. 2004. Pengendalian gulma epifit pada kelapa sawit. Warta. 12(1):13-17.

Manual Referensi Agronomi. 2008. Buku Pedoman Teknis Kelapa Sawit. Jakarta (ID): Minamas Plantation.

Pahan, I. 2008. Kelapa Sawit: Manajemen Agribisnis dari Hulu Hingga Hilir. Jakarta (ID): Penebar Swadaya.

[PPKS] Pusat Penelitian Kelapa Sawit. 2005. Seri Buku Saku Tanaman Penutup Tanah dan Gulma pada Kebun Kelapa Sawit. Medan (ID).

Sukman, Y., Yakup. 2002. Gulma dan Teknik Pengendaliannya. Jakarta (ID): Raja Grafindo Persada.

Sunarko. 2009. Budi Daya dan Pengelolaan Kebun Kelapa Sawit dengan Sistem Kemitraan. Agromedia Pustaka, Jakarta.

Syahputra, E., Sarbino, Dian, S. 2011. Weeds assessment di perkebunan kelapa sawit lahan gambut. J.Tek Perkebunan \& PSDL. 1:37-42.

Tjitrosoedirdjo, S., Utomo, I, H., Wiroatmodjo, J. 1984. Pengelolaan Gulma di Perkebunan. Jakarta (ID): PT Gramedia. 